\title{
Diversity of Lichens along Elevational Gradients in Forest Ranges of Chamarajanagar District, Karnataka State
}

\author{
S. Rashmi ${ }^{1}$, H. G. Rajkumar ${ }^{2^{*}}$ \\ ${ }^{1}$ PG Department of Botany, JSS college of Arts, Commerce and Science, Ooty road, Mysore, Karnataka, India \\ ${ }^{2}$ Department of studies in Botany, Manasagangotri, University of Mysore, Mysore 570 006, Karnataka, India \\ *Corresponding Author: dr.hgrajkumar@botany.uni-mysore.ac.in Telephone No.: +91-821-2419757, 2419758,
}

Available online at: www.isroset.org

Received: 01/Feb/2019, Accepted: 14/Feb/2019, Online: 28/Feb/2019

\begin{abstract}
The lichen species richness in Chamarajanagar district in Karnataka, India were assessed using altitudinal gradient, in order to compare distribution patterns of different growth forms, dominant families and diversity index. Four major forest ranges, Biligiriranga Hills, Himavad Gopalaswamy Hills, Malay Mahadeshwara Hills, and Shivanasamudra Falls were surveyed and a total of 97 lichens, belonging to 47 genera and 25 families were recorded. Physciaceae was found to be dominant family by 18 species under 8 genera, followed by Parmeliaceae with 16 species under 4 genera. Crustose type was dominated with $51 \%$, followed by foliose type with $38 \%$. Malay Mahadeshwara hills had highest lichen species richness and harboured 67 species, of which, 36 species were crustose type and 28 species were foliose type. Shannon-weiner index ranged from 3.85- 2.45 and Simpson index of diversity ranged from 0.02-0.09. Luxuriant growth of lichens was recorded at the altitude of mid elevation with degree of abundance, density, frequency and distribution of the lichen species compared to other elevation. The present study provided baseline data of lichen diversity, which helps in understanding the relationship between distribution of lichen species along different elevation bands and vegetation types.
\end{abstract}

Keywords-Biodiversity, Deciduous forest, Physciaceae, Corticolous, MM Hills

\section{INTRODUCTION}

Lichens, one of the most successful symbiotic associations of a fungus, a green and/ or blue green alga, are known to inhabit nearly all the terrestrial domains of the planet [1]. Lichens are the early land colonizers of terrestrial habitats and perhaps the oldest living creatures on the Earth [2]. To know the spatial patterns in biodiversity along environmental gradients, is a central theme in ecology [3]. Elevation gradients distributed across the globe are a powerful test system for understanding biodiversity [4]. Elevation gradient studies on diversity and distribution of lichens has been undertaken across the world [5- 8]. In Karnataka, diversity and distribution pattern of lichens was studied only in midelevation wet Evergreen forest of Southern Western Ghats [9]. Southernmost part of Karnataka state lies Chamarajanagar district. The forest regions in this district run east from the Western Ghats to the river Cauvery and forms a forest ecological corridor that connects the Eastern Ghats and Western Ghats. This district is unique because it has scrub, dry deciduous, moist deciduous, semi-evergreen, evergreen and shola forests. It is also known for its many endemic species of plants including valuable medicinal ones. Forests in this district have been conserved to protect habitats like flora, fauna and cryptogamic forms like algae, bryophytes, pteridophytes and lichens. Lichens can provide valuable information about medicinal values and environmental conditions around the forest area. Enumeration of lichens in this region is not reported. Hence, in the present study forest ranges with different elevation gradients has been undertaken in Chamarajanagar district, with particular reference to understand the species richness, diversity, abundance, frequency, growth form and ecological adaptation of lichens.

\section{METHODOLOGY}

\section{Topography of the Study Area}

Chamarajanagar is the southernmost district in the state of Karnataka, India. Chamarajanagar district is divided into 3 taluks: Yelandur taluk, Kollegal taluk and Gundlupet taluk (Figure 1). Major and popular mountain ranges from each taluk has been selected for the study. Sampling sites were distributed at various elevations in the district. 


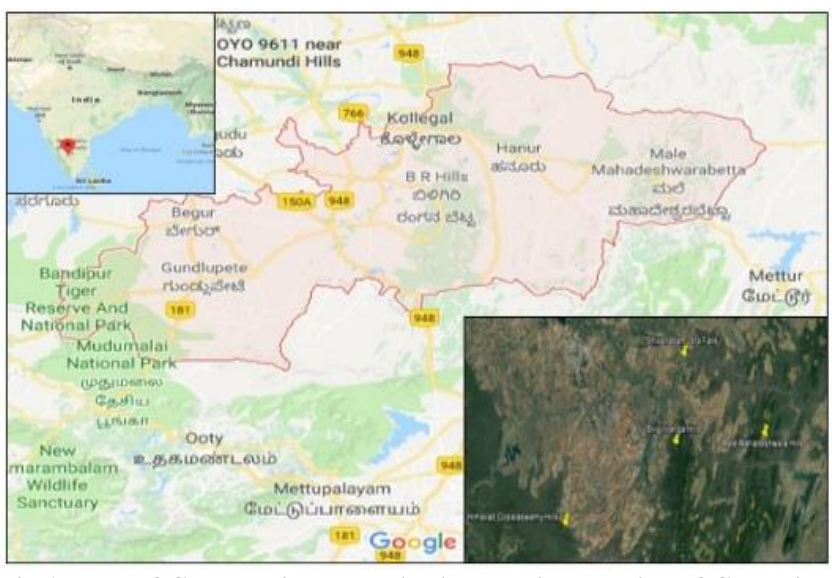

Fig 1: Map of Chamarajanagar District showing location of Collection sites (Source: Google map and Google earth)

Biligiriranga Hills also known as BRT Wildlife Sanctuary (Yelandur Taluk) is one of the famous Biodiversity and Hill station in the world and is rarest wildlife sanctuary. Male Mahadeshwara Hills (Kollegal Taluk) popularly called as MM Hills. It is a Holy place believed to have 777 wide hills, 77 important hills, 7 lively hills around. Shivanasamudra Falls (Kollegal Taluk), the Kaveri with its numerous branches falls down from 75 to 100 feet. All round falls one can see a number of hillocks. Himavad Gopalaswamy Hills (Gundlupet Taluk). It is an important Hill Station and Pilgrim Centre (Table 1).

Table 1: Geographical Parameters of lichen collection sites in

Chamarajanagara district

\begin{tabular}{|c|c|c|c|c|}
\hline Site & Locality & Altitude & Latitude & Longitude \\
\hline 1 & Biligiriranga Hills & $1500 \mathrm{~m}$ & $11^{\circ} 59^{\prime} 43.74^{\prime \prime} \mathrm{N}$ & $77^{\circ} 08^{\prime} 33.79^{\prime \prime} \mathrm{E}$ \\
\hline 2 & $\begin{array}{c}\text { Himavad } \\
\text { Gopalaswamy Hills }\end{array}$ & $1450 \mathrm{~m}$ & $11^{\circ} 43^{\prime} 26.72^{\prime \prime} \mathrm{N}$ & $76^{\circ} 35^{\prime} 21.40^{\prime \prime} \mathrm{E}$ \\
\hline 3 & $\begin{array}{c}\text { Malay } \\
\text { Mahadeshwara Hills }\end{array}$ & $1300 \mathrm{~m}$ & $12^{\circ} 01^{\prime} 30.87^{\prime \prime} \mathrm{N}$ & $77^{\circ} 33^{\prime} 54.87^{\prime \prime} \mathrm{E}$ \\
\hline 4 & $\begin{array}{c}\text { Shivanasamudra } \\
\text { Falls }\end{array}$ & $700 \mathrm{~m}$ & $12^{\circ} 17^{\prime} 37.03^{\prime \prime} \mathrm{N}$ & $77^{\circ} 10^{\prime} 05.50^{\prime \prime} \mathrm{E}$ \\
\hline
\end{tabular}

\section{Lichen Sampling}

Field trips were executed to collect lichen growing on different substrata were sampled by belt transact method. Each transect measuring 50x10 m laid in different locations of the study area. A total of 20 transects was laid in 4 different locations in the study area. All species of lichens found in sampling area were harvested and species that are tightly adhered to bark or rock were collected with the help of chisel and hammer. Immediately after collection, samples were cleaned and wrapped in a tissue paper and stored in paper bags. Collected specimens were numbered and preserved in lichen herbarium packet $(17 \mathrm{cmX} 10 \mathrm{~mm})$ with details of the locality and deposited in the herbarium of the
Department of studies in Botany, Manasagangotri, University of Mysore, Karnataka, India.

\section{Identification of Lichen Species}

The external morphology was studied using a stereomicroscope. The anatomy of the thallus and apothecia were studied under a compound microscope. The anatomical structures were studied after taking the section of dry material with the help of safety razor blade and the sections were mounted in water or on cotton blue in lactophenol. The colour of medulla, epithecium, hypothecium and ascus were recorded. The shape and size of the asci, ascospores and conidia were measured. The measurements of the thallus, medulla, epithecium and hymenium were generally recorded from the sections mounted on cotton blue. The thallus size was measured in centimeter, lobe size and ascocarps in millimeter and thallus medulla, epithecium, hymenium thickness, asci and ascospores size in millimicron. Chemical test of the specimens includes- colour spot tests $(\mathrm{K}, \mathrm{C}, \mathrm{KC}$ and $\mathrm{P}$ test) and thin layer chromatography (TLC) test through cold extraction method. Identification was carried out by consulting suitable keys to identify lichens [10-13].

\section{Data Analysis and Interpretation}

Lichen assemblages were quantitatively analyzed for density and frequency. Relative frequency $(\mathrm{RF})$ and relative density (RD) were determined [14]. $\mathrm{RF}=100 \mathrm{x}$ (frequency of species $I /$ sum of frequency values of all species), and $R D=100 \times$ (density of species I/sum of density values of all species). The importance value index (IVI) used here is the sum of the relative frequency and relative density. Frequency distribution, alpha diversity - Shannon-Weiner diversity index $\left(\mathrm{H}^{\prime}\right)$ and Simpson diversity index (D') have been used to assess species diversity [15]. Alpha diversity $\left(\mathrm{H}^{\prime}\right)$ was estimated as the Shannon-Wiener index: $\mathrm{H}^{\prime}=\Sigma p i \ln p i$, Where, $p i=$ density (number of thalli) of the species, $i /$ density of all species. All statistical analyses were performed using SPSS.

\section{RESULTS}

The present study deals with the systematic survey of lichens in forest ranges along with elevational gradient in Chamarajanagar district in Karnataka state which is bordering with Kerala and Tamil Nadu states. A total of 97 lichens, belonging to 47 genera and 25 families were recorded from 35 transects of 4 localities namely; Biligiriranga Hills, Male Mahadeshwara Hills, Shivanasamudra Falls and Himavad Gopalaswamy Hills (Table 2). 
Table 2: List of lichen flora enumerated from Chamarajanagar district

\begin{tabular}{|c|c|c|c|c|c|c|c|c|c|}
\hline \multirow[t]{2}{*}{$\begin{array}{l}S l \\
N o\end{array}$} & \multirow[t]{2}{*}{$\begin{array}{c}\text { Lichen samples } \\
(* \text { new record to Karnataka) }\end{array}$} & \multirow[t]{2}{*}{ Family } & \multirow[t]{2}{*}{$\begin{array}{l}\text { Growth } \\
\text { form }\end{array}$} & \multirow[t]{2}{*}{ Substratum } & \multicolumn{4}{|c|}{$\begin{array}{c}\text { Collection sites } \\
\text { Values in Importance Value Index } \\
\text { (IVI) }\end{array}$} & \multirow[t]{2}{*}{$\begin{array}{l}\text { Frequency } \\
\text { distribution }\end{array}$} \\
\hline & & & & & BRH & HGH & MMH & SSF & \\
\hline 2 & Arthonia medusula (Pers.) Nyl. & Arthoniaceae & Crustose & Bark & - & 2.06 & 1.91 & 2.3 & $75 \%$ \\
\hline 3 & Arthonia radiata (Pers.) Ach* & Arthoniaceae & Crustose & Bark & 3.30 & 3.95 & - & - & $50 \%$ \\
\hline 4 & Bacidia alutacea (Krempelh.) Zahlbr. & Bacidiaceae & Crustose & Bark & - & 4.06 & - & - & $25 \%$ \\
\hline 5 & Bacidia incongruens (Stirton) Zahlbr & Bacidiaceae & Crustose & Bark & 3.80 & - & 3.51 & - & $50 \%$ \\
\hline 8 & $\begin{array}{l}\text { Brownliella cinnabarina (Ach.) S.Y. } \\
\text { Kondr., Karnefelt, A. Thell, Elix, J.Kim, } \\
\text { A.S. Kondr. \& J.S. Hur.* }\end{array}$ & Teloschistaceae & Crustose & Rock & 5.31 & 7.14 & - & - & $50 \%$ \\
\hline 9 & $\begin{array}{l}\text { Buellia indicaS.R. Singh \& D.D. } \\
\text { Awasthi }\end{array}$ & Physciaceae & Crustose & Rock & 3.46 & 6.41 & 4.47 & 7.61 & $100 \%$ \\
\hline 10 & $\begin{array}{l}\text { Buellia hemisphericaS.R. Singh \& D.D. } \\
\text { Awasthi }\end{array}$ & Physciaceae & Crustose & Bark & - & 5.89 & - & - & $25 \%$ \\
\hline 14 & Caloplaca abuensisY. Joshi \& Upreti* & Teloschistaceae & Crustose & Bark & - & - & - & 5.67 & $25 \%$ \\
\hline 15 & $\begin{array}{l}\text { Caloplaca atrosanguinea (G. Merr.) } \\
\text { Lamb* }\end{array}$ & Teloschistaceae & Crustose & Bark & 1.78 & 2.43 & 5.63 & - & $75 \%$ \\
\hline 16 & $\begin{array}{l}\text { Caloplaca flavorubescens (Huds.) J.R. } \\
\text { Laundon }\end{array}$ & Teloschistaceae & Crustose & Bark & 1.01 & 3.49 & - & - & $50 \%$ \\
\hline 17 & Caloplaca bassiae (Ach.) Zahlbr * & Teloschistaceae & Crustose & Bark & 2.12 & - & - & - & $25 \%$ \\
\hline 18 & Caloplaca poliotera (Nyl.) J. Steiner* & Teloschistaceae & Crustose & Rock & - & - & 1.91 & - & $25 \%$ \\
\hline 19 & $\begin{array}{l}\text { Caloplaca suboahuensis Y. Joshi \& } \\
\text { Upreti* }\end{array}$ & Teloschistaceae & Crustose & Rock & - & - & 3.58 & - & $25 \%$ \\
\hline 20 & Caloplaca subnigricans Magnusson* & Teloschistaceae & Crustose & Bark & 3.63 & - & 3.44 & 4.24 & $75 \%$ \\
\hline 21 & Caloplaca subsoluta (Nyl.) Zahlbr* & Teloschistaceae & Crustose & Bark & 4.40 & - & 4.33 & - & $50 \%$ \\
\hline 22 & Candelaria concolor (Dicks.) Stein & Candelariaceae & Foliose & Bark & 6.49 & 4.63 & 5.62 & 4.52 & $100 \%$ \\
\hline 23 & $\begin{array}{l}\text { Canoparmelia texana (Tuck.) Elix \& } \\
\text { Hale* }\end{array}$ & Parmeliaceae & Foliose & Bark & - & - & 1.91 & - & $25 \%$ \\
\hline 31 & $\begin{array}{l}\text { Diorygma pruinosum (Eschw.) Kalb, } \\
\text { Staiger \& Elix* }\end{array}$ & Graphidaceae & Crustose & Bark & 1.95 & - & - & - & $25 \%$ \\
\hline 32 & Diploschistes cinereocaesius (Sw.) Vain & Thelotremataceae & Crustose & Rock & - & - & 4.47 & - & $25 \%$ \\
\hline 33 & $\begin{array}{l}\text { Diploschistes scruposus (Schreber) } \\
\text { Norman }\end{array}$ & Thelotremataceae & Crustose & Rock & 3.46 & - & 2.20 & - & $50 \%$ \\
\hline 34 & Dirinaria applanate (Fee) Awas. & Physciaceae & Foliose & Bark & 4.54 & 5.32 & 5.47 & 6.16 & $100 \%$ \\
\hline 35 & Dirinaria confluens (Fr.) Awas. & Physciaceae & Foliose & Bark & 5.64 & 4.63 & 4.09 & - & $75 \%$ \\
\hline 36 & $\begin{array}{l}\text { Dirinaria papillulifera (Nyl.) D. D. } \\
\text { Awasthi* }\end{array}$ & Physciaceae & Foliose & Bark & - & 1.31 & - & - & $25 \%$ \\
\hline 37 & Flavoparmelia caperata $(\mathrm{L}$.) Ach. & Parmeliaceae & Foliose & Bark & 5.31 & 9.21 & 4.16 & 11.45 & $100 \%$ \\
\hline 38 & Graphis homichlodes Redinger & Graphidaceae & Crustose & Bark & - & - & 2.20 & - & $25 \%$ \\
\hline 39 & Graphis script (L.) Ach. & Graphidaceae & Crustose & Bark & 2.61 & 1.54 & - & - & $50 \%$ \\
\hline 40 & $\begin{array}{l}\text { Haemotaemma puniceum (Sm. Ex Ach.) } \\
\text { Massal. }\end{array}$ & Haematommataceae & Crustose & Bark & 2.78 & - & 2.34 & - & $50 \%$ \\
\hline 41 & $\begin{array}{l}\text { Hemithecium nakanishiana (Patw. \& } \\
\text { kulk.) Makhija \& Dube }\end{array}$ & Graphidaceae & Crustose & Bark & 1.26 & 1.66 & - & - & $50 \%$ \\
\hline 42 & $\begin{array}{l}\text { Heterodermia comosa (Eschw.) } \\
\text { Follmann \& Redón }\end{array}$ & Physciaceae & Foliose & Bark & 2.89 & 3.95 & - & - & $50 \%$ \\
\hline 43 & $\begin{array}{l}\text { Heterodermia hypocaecia (Yasuda) } \\
\text { D.D. Awasthi }\end{array}$ & Physciaceae & Foliose & Bark & - & 5.20 & 3.51 & - & $50 \%$ \\
\hline 44 & Heterodermia obscurata (Nyl.) & Physciaceae & Foliose & Rock & 3.22 & - & 4.52 & - & $50 \%$ \\
\hline 45 & Heterodermia podocarpa (Bèl.)Awas. & Physciaceae & Foliose & Bark & 5.75 & - & - & - & $25 \%$ \\
\hline
\end{tabular}




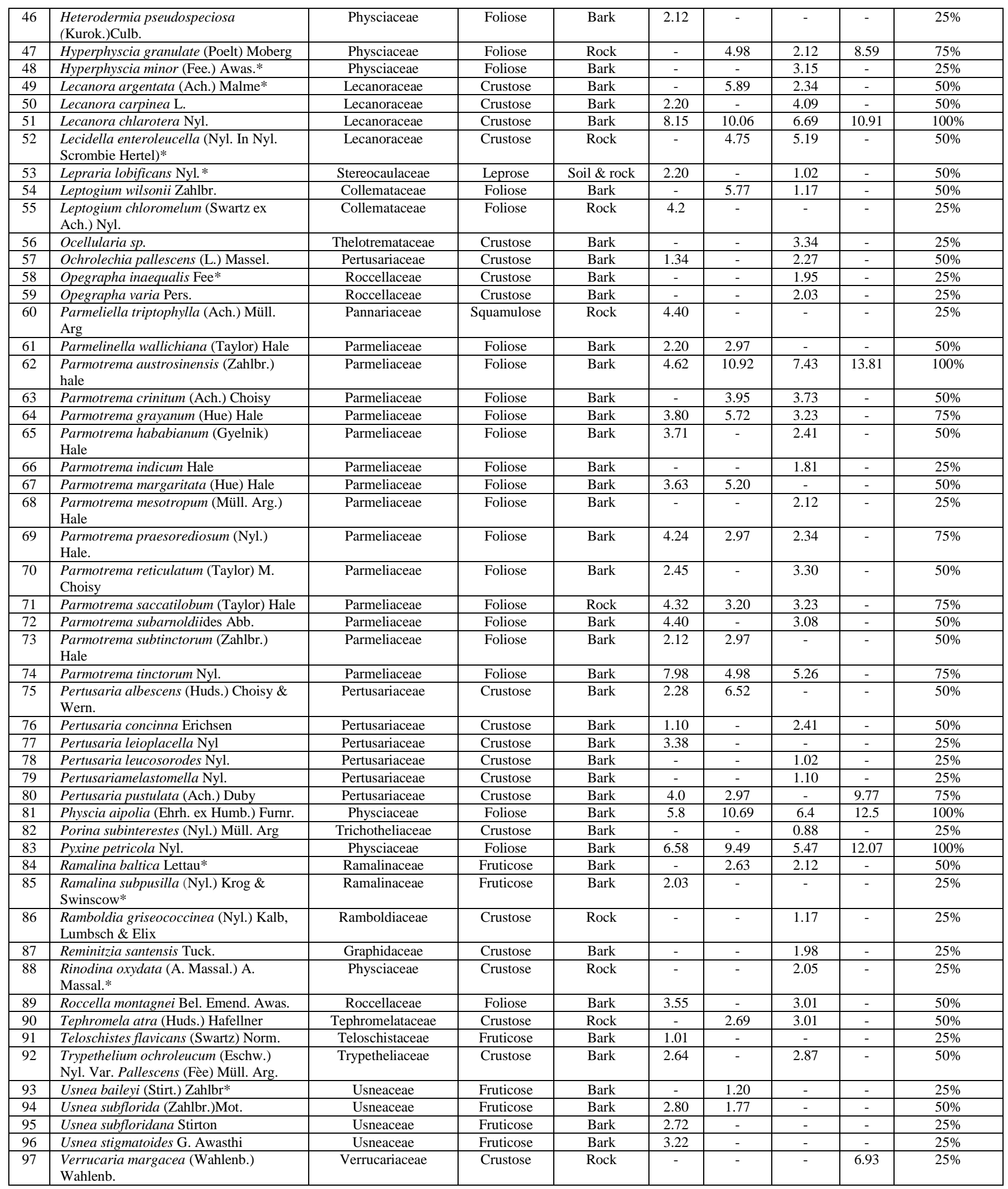

Collection sites: 1. HGH: Himadgopalaswamy hills, 2. BRH: Biligirirangana hills, 3. MMH: Malay mahadeshwara hills, 4. SSF: Shivanasamudra falls 
Among the 97 species recorded from this region, 28 species are new reports from Karnataka state. Physciaceae was dominated by 18 species under 8 genera, Parmeliaceae with 16 species under 4 genera, followed by Teloschistaceae with 10 species under 2 genera, Pertusariaceae with 7 species under 2 genera and Graphidaceae with 6 species under 3 genera (Figure 2).

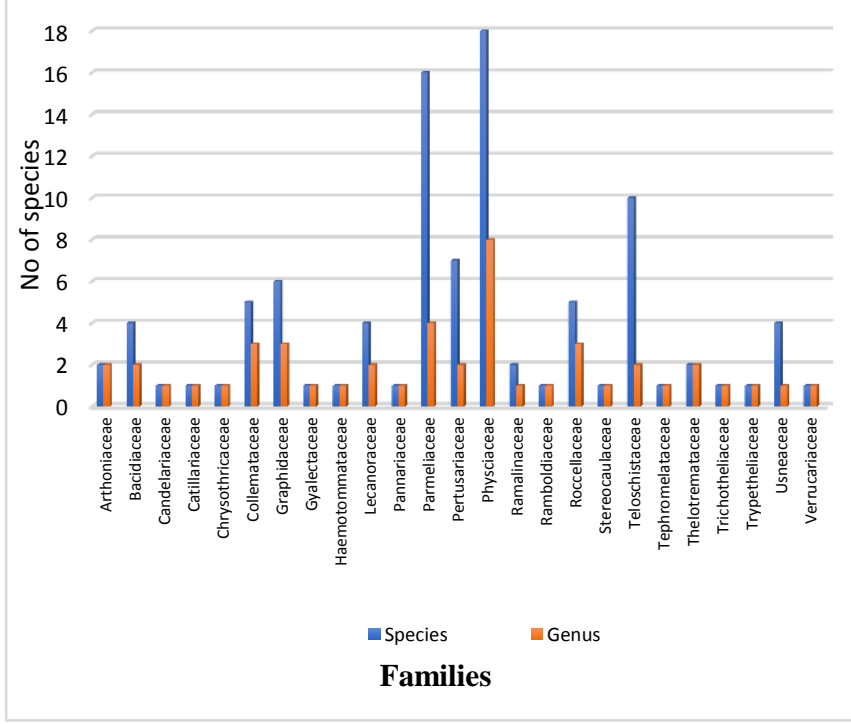

Fig 2: Dominant lichen families with respect to species richness in Chamarajanagar district

Crustose type growth forms were abundant with $51 \%$, followed by foliose type growth forms with $38 \%$, fruticose type growth forms with $8 \%$ and squamulose type growth forms with $1 \%$ (Figure 3). High diversity of lichens was encountered in Male Mahadeshwara hills with 67 species, in which crustose growth form was more with 36 species and foliose with 28 species (Figure 4).

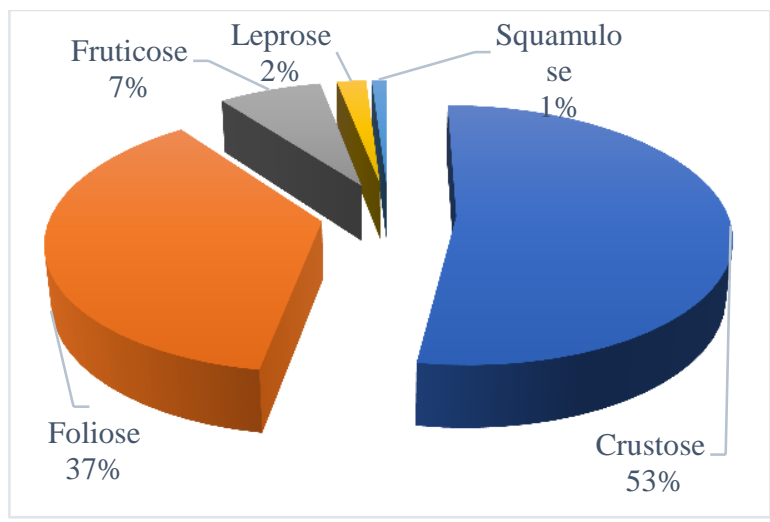

Fig 3: Percentage of different growth forms of lichens in Chamarajanagar district

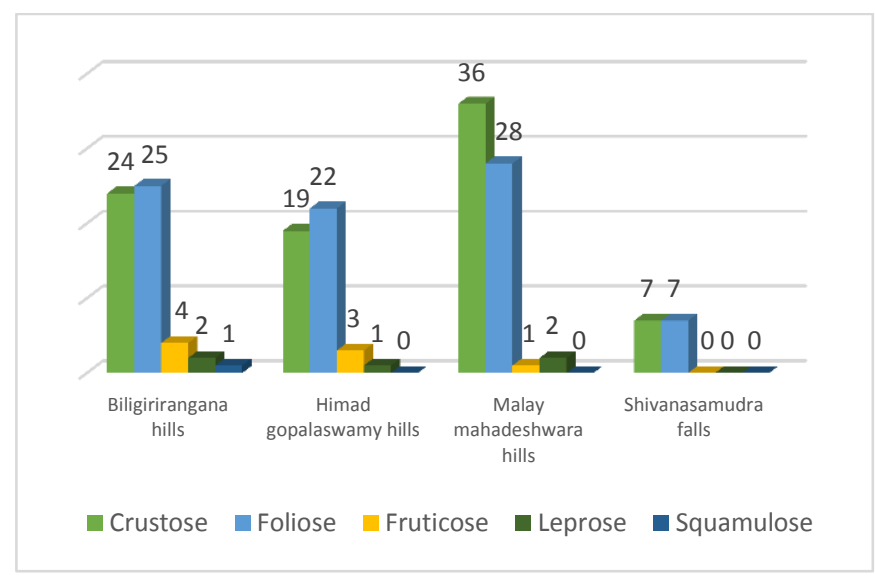

Fig 4: Number of lichen growth forms in each studied locality in Chamarajanagar district

The different types of lichens recorded in this region were from the mid elevation level (950-1100). The forest type varies from evergreen forests to dry deciduous forests. The next richly dense place with lichen colonization of 55 species was Biligiriranga hills commonly called BR Hills. The forest vegetation types here were; scrub, deciduous, riparian, evergreen, sholas and grasslands. Among all the study sites, BR hills had the high range mountain peaks and at high altitude (1350-1450 m) only few lichens of Heterodermia and Parmotrema were recorded less density and abundance. Density of macrolichens was more compared to microlichens. But in mid elevation (1100- 1350m) abundance, density, frequency and distribution of lichens was recorded luxuriantly. At low elevation (800-1000m) density and abundance of crustose lichens was more. The next highest elevated region $(1500 \mathrm{~m})$ is Himadgopalaswamy hills which is situated in the core area of the Bandipur National Park and is frequented by wildlife. Dense fog predominates and covers the hills round the year, with moist deciduous forest type. In this forest range, density of macrolichens was found to be more with 25 species compared to the microlichens with 20 species at elevation of 1350-1450m). Shivanasamudra falls has a segmented water fall of river Kaveri with Scrub forest. Not much lichen colonization was found, density of lichens was very poor with 14 species.

Among the microlichens from all the regions Buellia indica, Cryptothecia culbersonae, Chrysothrix candelaris Lecanora chlarotera, Graphis sp., Pertusaria pustulata and macrolichens like Candelaria concolor, Dirinaria applanata, Dirinaria confluens, Flavoparmelia caperata, Parmotrema 
austrosinensis, Parmotrema grayanum, Parmotrema praesorediosum, Parmotrema tinctorum, Physcia aipolia and Pyxine petricola had high Important Value Index. ShannonWeiner index ranged from 3.85-2.45 and Simpson index of diversity ranged from 0.02-0.09. Among the four studied regions MM Hills harboured luxuriant growth of species with highest Shannon- Simpson index of 3.98 and 0.02 respectively, and less distribution was observed in Shivanasamudra falls with comparatively less ShannonSimpson index of 2.45 and 0.09 respectively (Table 3).

Table 3: Lichen richness in the study sites of Chamarajanagar district

\begin{tabular}{|c|c|c|c|c|c|}
\hline Site & Locality & $\begin{array}{c}\text { Shannon- } \\
\text { weiner index }\end{array}$ & $\begin{array}{c}\text { Simpson } \\
\text { index of } \\
\text { diversity }\end{array}$ & $\begin{array}{c}\text { Total } \\
\text { individual }\end{array}$ & $\begin{array}{c}\text { Total } \\
\text { number of } \\
\text { species }\end{array}$ \\
\hline 1 & Biligiriranga Hills & 3.85 & 0.02 & 1231 & 57 \\
\hline 2 & $\begin{array}{c}\text { Himavad } \\
\text { Gopalaswamy } \\
\text { Hills }\end{array}$ & 3.49 & 0.03 & 897 & 43 \\
\hline 3 & $\begin{array}{c}\text { Malay } \\
\text { Mahadeshwara } \\
\text { Hills }\end{array}$ & 3.98 & 0.02 & 1422 & 67 \\
\hline 4 & $\begin{array}{c}\text { Shivanasamudra } \\
\text { Falls }\end{array}$ & 2.45 & 0.09 & 372 & 14 \\
\hline
\end{tabular}

\section{DISCUSSION}

In the present study, it was observed that, the species richness increased as elevation increases, up to a certain point, creating a "diversity bulge" at middle elevations [16]. Elevation was more important than forest structure in driving taxonomic and functional diversity. While the species richness with increase elevation, decrease in functional diversity revealed that community patterns shift with elevation from random to clustered, reflecting the selection for key shared traits. Higher elevations favoured species with a complex growth form (which takes advantage of high moisture) and asexual reproductive mode (facilitating establishment under low temperature conditions) [17].

As elevation increased, total area decreased; thus, there were more species present at middle elevations than at low and high elevations. There are generally three patterns of species richness; a monotonic decline in species richness from low to high elevation, a hump-shaped pattern with maximum at mid-elevations and a constant from the lowlands to mid elevations followed by a strong decline further up which indicates that the maximum number of species had been confined in the mid elevations [18]. The elevation was also clearly effective on both the number and the composition of the epiphytic lichen communities. Climatic parameters like; temperature, rainfall, evaporation, are known to be closely related to altitude. For this reason, the number of species was more in the highest zone. The preferences of some species were reported to be concentrated in $1300-1600 \mathrm{~m}$ and 1800-1900m elevation zones [19].

Families such as Graphidaceae, Thelotremataceae are generally observed to be found commonly in lowland forests [20] which corroborate our study in that, the population of crustose lichens was found to be more in low elevated areas, especially in BR hills and MM hills. Similar observation was reported from Chogoria, a wet forest type in Mt. Kenya forest, where high abundance of crustose micro lichens at lower elevation was observed and macro lichens were abundant at higher altitudes [21]. Further, it was apparent that, the numbers of foliose lichens are increasing with the increase of altitude. In most temperate and boreal forests, with light exposed trees, had richer lichen vegetation than the trees of the interior forest [22]. Mid-elevation peaks had a unimodal peak in diversity at intermediate elevations $(4300 \mathrm{~m})$ with $25 \%$ or more species than at the base and the top of the mountain [23]. In a similar work, the effect of elevation was studied on lichen diversity in seven spatially separated sites of Zanskar valley, in Ladakh region of the Himalayan state of Jammu and Kashmir and found a significant linear relationship between total lichen diversity and elevation, where a gradual decrease in lichen diversity was observed with increase in elevation [24].

Elevational gradients of terricolous lichen species richness in the Western Himalaya and the total species richness showed a unimodal relationship with elevation, where the highest species richness was observed at mid elevations $(3,200 \mathrm{~m})$ [25], which is similar to our observation in the present study. Unimodal relationship of lichen species richness with elevation was also reported from Nepal [26], where the maximum modelled total richness occurred in 3100-3400m, whereas the observed maximum richness (144 species) was at approximately $4000 \mathrm{~m}$. The lichen diversity in the crowns of trees at mid elevation seems to be somewhat similar to that at lower elevation although tree species are different. At mid elevation, tree trunks get only diffused light while the canopy gets more direct light. The difference in distribution and diversity observed on barks could be mainly due to light condition prevailing at mid elevations [27]. The number of lichen species showed decline towards the high elevation gradient, in which rock 
inhabiting species exhibit their dominance in higher altitude while, soil inhibiting lichens dominated in the lower altitude [28].

The majority of the parmelioid genera and species of Taiwan are distributed primarily in submontane-montane elevations (500-2,500 m) located in the meridional climatic zone [29]. Basic groundwork must be comprehended in order to meet the nation's needs and also to strive towards the biotechnology industry. Better lichen sample representation of the lichen should be collected. Furthermore, since the lichens can only be identified through its fruiting bodies, the task of collecting sterile lichens should be avoided [30].

\section{CONClusion}

The present study indicates the richness of lichen diversity in the Chamarajanagar district of Karnataka state. It had varied vegetation with different forest types namely; scrub, dry deciduous, moist deciduous, semi-evergreen, evergreen and shola forests. The study revealed that, as the elevation increased from lowland to mountain peak, the total area also decreased, leading to highest lichen species richness in terms of abundance, density, frequency and distribution at mid elevation, where luxuriant growth of lichen species was observed when compared to lowland and high elevation mountain peaks. The enumeration lichens species gave a baseline of lichen diversity of Chamarajanagar district of Karnataka, which is a lichenologically unexplored region and addition to Indian lichen inventory.

\section{ACKNOWLEDGMENT}

The authors are thankful to University of Mysore for awarding UGC NON-NET fellowship to the first author to carry out the research work.

\section{REFERENCES}

[1]. Galloway DJ, Biodiversity: a lichenological perspective. Biodiversity and Conservation.; 1, pp- 312-323, 1992.

[2]. Bhat M, Verma S, Upreti DK. Lichens for Sustainable Environment. International Journal of Environmental Research and Development, 4(4), pp- 325-328, 2014.

[3]. Zou F, Chen G, Yang Q, Li, Y. Bird Species Richness along an Elevational Gradient in a Forest at Jianfengling, Hainan Island, China. Zoological Studies, 51(3), pp- 362-371, 2012.

[4]. McCain CM. Global analysis of bird elevational diversity. Global Ecol. Biogeogr., 18, pp- 346-360, 2009.

[5]. Bruun HH, Moen J, Virtanen R, Grytnes JA, Oksanen L, Angerbjörn A. Effects of altitude and topography on species richness of vascular plants, bryophytes and lichens in alpine communities. Journal of Vegetation Science, 17, pp- 37- 46, 2006.
[6]. Pinokiyo A, Singh KP, Singh JS. Diversity and distribution of lichens in relation to altitude within a protected biodiversity hot spot, north-east India. Lichenologist, 40, pp- 47-62, 2008.

[7]. Senglek S, Polyiam W, Boonpragob K. Diversity of lichens along the elevation gradient at Khao Yai National park, Thailand. The 7th International Association for Lichenology Symposium, 115 (2B-P3) 2012.

[8]. Kumar J, Khare R, Rai H, Upreti DK, Tayade A, Hota S, Chaurasia OP, Srivastava RB. Diversity of lichens along altitudinal and land use gradients in the Trans Himalayan cold desert of Ladakh. Nature and Science, 10(4), pp- 1-9, 2012

[9]. Vinayaka KS, Chetan HC, Mesta AR. Diversity and Distribution Pattern of Lichens in the Mid Elevation Wet Evergreen Forest, Southern Western Ghats, India. International Journal of Research Studies in Biosciences, 4, pp- 15-20, 2016.

[10]. Awasthi DD. A key to the macrolichens of India and Nepal. Journal- Hattori Botanical Laboratory, 65, pp- 207-302, 1988

[11]. Awasthi DD. A key to the microlichens of India, Nepal and Sri Lanka. Bibliotheca Lichenologica, 40, pp- 1-336, 1991.

[12]. Goward T, McCune B, Meidinger D. The Lichens of British Columbia, Illustrated Keys: Part 1- Foliose and Squamulose Species. Ministry of Forests Research Program. 1994.

[13]. Malcolm WM, Galloway DJ. The New Zealand lichens: Checklist, Key, and Glossary. Museum of New Zealand Te Papa Tongarewa Wellington. 1997.

[14]. Phillips EA. Methods of Vegetation Study. New York: Henry Holt \& Co. Inc. 1959.

[15]. Pielou EC. Ecological Diversity. John Wiley and Sons, Inc. 1975.

[16]. Stevens GC. The elevational gradient in altitudinal range: An extension of Rapoport's latitudinal rule to altitude. The American Naturalist, 140(6), pp- 893-911, 1992.

[17]. Bässler C, Cadotte MW, Beudert B, Heibl C, Blaschke M, Bradtka JH, Langbehn T, Werth S, Müller J. Contrasting patterns of lichen functional diversity and species richness across an elevation gradient, 2015.

[18]. Negi HR, Upreti DK. Species diversity and relative abundance of lichens in Rumbak catchment of Hemis National Park in Ladakh. Current science, 78(9), pp-1105-1112, 2000.

[19]. Cobanoglu G, Sevgi O. Analysis of the distribution of epiphytic lichens on Cedrus libani in Elmali Research Forest (Antalya, Turkey). Journal of Environmental Biology, 30(2), pp- 205212, 2009.

[20]. Sipman HJM. Lichens from Mount Kinabalu. Tropical Bryology, 8, pp- 281-314, 1993.

[21]. Muigai KP. Diversity, ecology and altitudinal distribution of corticolous lichens in Mount Kenya tropical montane forest (Doctoral thesis). 2012

[22]. Rose F. Temperate forest management: its effects on the bryophyte and lichen floras and habitats. In: Bates, J.W., Farmer, A.D. (Eds), Bryophytes and Lichens in a Changing Environment. Oxford: Oxford Science, pp-211-233, 1992.

[23]. McCain CM, Grytnes J. Elevational Gradients in Species Richness. In: Encyclopedia of Life Sciences (ELS). John Wiley \& Sons, Ltd: Chichester. 2010. DOI: 10.1002/9780470015902.a0022548

[24]. Kumar J, Rai H, Khare R, Upreti DK, Dhar P, Tayade AB, Chaurasia OP, Srivastava RB. Elevational controls of lichen communities in Zanskar valley, Ladakh, a Trans Himalayan cold desert. Tropical plant research, 1(2), pp- 48- 54, 2014.

[25]. Rai H, Khare R, Baniya CB, Upreti DK, Gupta RK. Elevational gradients of terricolous lichen species richness in the Western Himalaya. Biodivers Conserv, 24, pp-1155- 1174. 2015. 
[26]. Baniya CB, Solhøy T, Gauslaa Y, Palmer MW. The elevation gradient of lichen species richness in Nepal. The Lichenologist, 42(1), pp- 83- 96, 2010.

[27]. Gunawardana KW, Wijeyaratne SC. Some studies on the diversity and distribution of lichens on Ritigala Mountain. Proceedings of International Forestry and Environment Symposium, 37, 2000.

[28]. Singh J, Upreti DK, Dubey AK. Effect of elevation gradient on the distribution of lichens and mosses of central Himalayan region, Uttarakhand, India. Journal of Environmental Science and Technology, 3(5), 2016.

[29]. Lai M. Parmelioid lichen biodiversity and distributional ecology in Taiwan. Fung. Sci. 16 (3,4), pp- 39-46, 2001.

[30]. Zulkifly S, Kim YS, Majid MA, Merican AF. Distribution of Lichen Flora at Different Altitudes of Gunung Machincang, Langkawi Islands, Malaysia. Sains Malaysiana, 40(11), pp1201-1208, 2011. 